\title{
POPULATION OF THE UPPER AND MIDDLE KAMA BASIN IN THE NEOLITHIC
}

(C) 2019

Demakov Denis Aleksandrovich, postgraduate student of Domestic and World History, Archeology Department Lychagina Evgenia Leonidovna, candidate of historical sciences, associate professor of Domestic and World History, Archeology Department Perm State Humanitarian Pedagogical University (Perm, Russian Federation)

Abstract. The paper gives a description of the landscapes formed in the Upper and Middle Kama basin in the Holocene. First of all, we talk about the first river terraces and the most ancient floodplain generations. In the Upper and Middle Kama basin, 78 Neolithic sites are known. During the mapping of the study area, 4 micro regions were identified with a large concentration of Neolithic settlements and territories with no Neolithic sites are known. The first group includes: the old-channel formation of the Chashkinskoye Lake, the Berezovaya River and the Chusovsky Lake District, the old-channel formation of the Khomutovskoe Lake and surroundings of Perm. The second one is the Upper Kama in the Gainsky and Kosinsky District s of the Perm Region and middle flows of the Chusovaya and Sylva rivers. The analysis of Neolithic sites locations showed that there is a dependence on the first formed terraces and the most ancient floodplains of large water arteries. Actually the most of the sites were located on its tributaries rather than on the upper Kama river.

Keywords: upper and middle Kama river; Neolithic; archaeological sites; paleochannel analysis; floodplain generation; floodplain terrace; Holocene; old-channel lake; settlements concentration area; natural and climatic changes; reservoirs; mapping; paleochannels.

$* * *$

УДК 902.01/904

DOI 10.24411/2309-4370-2019-13203

Статья поступила в редакцию 25.03.2019

\section{ПЕРЕХОД ОТ МЕЗОЛИТА К НЕОЛИТУ НА ВЕРХНЕЙ ВОЛГЕ ПО РЕЗУЛЬТАТАМ ИЗУЧЕНИЯ КАМЕННОЙ ИНДУСТРИИ}

(C) 2019
Цветкова Наталия Александровна, специалист отдела научной документации Российский этнографический музей (2. Санкт-Петербург, Российская Федерация)

Аннотащия. Статья посвящена вопросу неолитизации Верхневолжского региона. На основании вопервых, изучения каменной индустрии со стоянок только с неорнаментированной/накольчатой керамикой; во-вторых, сопоставления типов орудий начального неолита и финального мезолита региона; в-третьих, изучения распространения сосудов с неорнаментированной/накольчатой орнаментацией на Европейской части России реконструируются детали культурных процессов в регионе. Переход к неолиту следует ассоциировать с разовыми контактами между автохтонным населением и носителями навыков изготовления посуды с разреженной накольчатой орнаментацией. Вероятно, первая посуда попала в регион в готовом виде. Отсутствие различий между каменными индустриями финального мезолита и начального неолита не свидетельствует о массовом притоке населения в регион. Попав в мезолитическую среду, традиция изготовления ранней накольчатой посуды не имела длительного продолжения и была прервана притоком населения, обладавшего навыками изготовления посуды с гребенчатой орнаментацией из сложно-рецептурного теста. Эпизод появления и распространения керамики с разреженной накольчатой орнаментацией, не сопровождавшийся существенными изменениями в облике каменного и костяного инвентаря, можно рассматривать как переходное время между мезолитом и неолитом.

Ключевые слова: Верхняя Волга; финальный мезолит; начальный неолит; неолитизация; культурогенез; бутовская культура; волго-окская культура; верхневолжская культура; накольчатая керамика; гребенчатая керамика; каменный инвентарь; технокомплекс; археологическая культура; культурная общность.

\section{Введение}

Переход к неолиту на Верхней Волге, как и во всей лесной зоне, отмечен появлением в материальной культуре керамических сосудов. Это событие датируется временем около 7100-7000 Uncal BP. Наиболее ранняя керамика характеризуется как неорнаментированная или посуда с овально-накольчатым орнаментом, для которой характерны плоские и приостренные донца, прямые венчики [1, с. 217]. Процесс неолитизации региона трактуется как трансформация бутовской мезолитической культуры в ранненеолитическую верхневолжскую с участием пришлого населения, владевшего навыками изготовления глиняной посуды [1, с. 213]. Начальный этап неолита в регионе соотносится с ранним этапом развития верхневолжской археологической культуры (далее - ВВК), основным маркером которого является керамика с разреженной тычково-накольчатой орнаментацией [2-4].

Каменный инвентарь ранней ВВК охарактеризован в литературе по материалам стоянок Окаёмово 5, 18/III (здесь и далее римская цифра обозначает порядковый номер культурного слоя на памятнике, арабская - номер литологического горизонта); Бели- 
Цветкова Н.А.

Переход от мезолита к неолиту на Верхней Волге по результатам изучения.

Исторические науки и археология

во 2; Альба; Давыдковская, Озерки 5/III, Шадрино IV. Отмечаются следующие его черты: 1) основной заготовкой является отщеп; 2) сокращается количество пластин по сравнению с финальным мезолитом; 3) преобладают пластины с нерегулярной огранкой; 4) для наконечников стрел и режущих орудий характерно изготовление на пластинах; 5) известны единичные костяные орудия с пазом и микропластинки - вкладыши преимущественно с приострённым краем 6) среди каменных наконечников стрел преобладают орудия с выделенным черешком/иволистной формы с подработкой пера и насада или с ретушью по периметру заготовки; иногда попадаются наконечники с двусторонней краевой ретушью; 8) разнообразные по формам скребки являются наиболее многочисленной категорией орудий; 9) среди резцов доминируют угловые преимущественно на отщепах [подробно см. 4, с. 18].

Такая весьма общая характеристика без количественных подсчетов каменной индустрии начального этапа неолита Верхней Волги до недавнего времени считалась достаточной. В свое время была обоснована культурная преемственность ранненеолитического населения от мезолитического. Детально охарактеризованная каменная индустрия бутовской культуры на позднем этапе её развития позволяла получить полное представление и о ранневерхневолжской [5; 6, с. 82].

Ситуация изменилась после того, как была выявлена культурная разнородность между ранней верхневолжской керамикой с накольчато-гребенчатой орнаментацией и более поздней верхневолжской посудой с ложношнуровой, прочерченной орнаментацией и с гребенчатыми оттисками [7, с. 156, 161]. Сейчас установлено, что верхневолжские гончары использовали тесто сложносоставных рецептов в вариантах «глина + шамот + органика» и «глина + шамот + органика + дресва». При этом использование шамота рассматривается в качестве культурного маркера ВВК. А.А. Бобринский установил, что возникновение сложных технологических традиций (многокомпонентные примеси в формовочных массах) на начальных этапах становления гончарства было обусловлено культурным смешением носителей простых традиций (однокомпонентные примеси в формовочных массах), [8, с. 71-72]. Появление примеси дресвы в поздней верхневолжской посуде объясняется контактами верхневолжского населения с носителями традиций изготовления керамики с ямочно-гребенчатым орнаментом. В ранней верхневолжской посуде без орнамента либо декорированной тычками/наколами в качестве примеси использовалась органика. Данное обстоятельство было принято Ю.Б. Цетлиным за основу для обособления волго-окской культуры (далее - ВОК) в качестве самостоятельной историко-культурной единицы, хронологически предшествовавшей ВВК [7; 9, с. 37].

Концепция ВОК подверглась серьезной критике. По мнению ряда исследователей в условиях формирования технологических традиций на раннем этапе становления гончарства наличие разных примесей не является показателем инокультурного влияния. О нем можно говорить только при условии наличия давно сложившихся технологических традиций в производстве сосудов. Кроме того, для выделения новой историко-культурной единицы требуется более широкая доказательная база, нежели разница в составе теста керамических сосудов [10, с. 41].

Исследования последних лет подтвердили разнородность компонентов ВВК. Технико-типологический анализ ее каменной индустрии позволил выделить качественно отличные друг от друга группы каменного инвентаря, каждая из которых сопровождается разнокультурной, по Ю.Б. Цетлину, керамикой. Для первой и более ранней индустрии (7100/7000-6600/6500 Uncal BP), характерны высокая роль пластины и приём минимальной модификации заготовок при вторичной обработке. Данная черта ярко выражена в облике наконечников стрел с подработкой острия пера и насада или с контурной ретушью, занимающей менее 3/4 поверхности пластины-заготовки. Этот инвентарь соответствует I-му этапу развития ВВК (волго-окской, по Ю.Б. Цетлину) и сопровождается ранней керамикой с разреженной тычково-накольчатой орнаментацией. Вторая группа изделий происходит со стоянок развитой и поздней верхневолжской АК (6600/6500-6000/5900 Uncal BP) и характеризуется использованием отщепа как основной заготовки для орудий и приёмом сплошного ретуширования наконечников острий и ножей, а также появлением техники производства тонких бифасов. Ее сопровождает керамика с ложношнуровым, прочерченным, пунктирным, гребенчатым орнаментом [11, с. 274-278].

Каменный инвентарь базовых памятников ВОК [7, с. 162] так и не был охарактеризован. В статье приводится детальная характеристика каменной индустрии начального этапа неолита Верхней Волги. На основании полученных данных анализируется правомерность обособления этих древностей в самостоятельную археологическую культуру.

\section{Источники}

В качестве источников использованы коллекции каменных изделий со стоянок, на которых в культурных слоях раннего неолита найдена только керамика с разреженной тычково-накольчатой орнаментацией. Это памятники, приуроченные к отложениям субаквального и субаэрального генезиса («на песке») Алексеевское I, Давыдковская, Котчище I, Нилова Пустынь, Шадрино IV и торфяниковые поселения Замостье $2 / 4 \mathrm{a} \quad(6385 \pm 150,6485 \pm 150, \quad 6720 \pm 150$, $6975 \pm 100,7030 \pm 100$ и $7105 \pm 150$ ВР), Окаёмово 18/III (6800 \pm 60 (ГИН-8416), Сахтыш ІІа/ІІг (6411 \pm 150 $(\mathrm{SPb}-1452) ; 6753 \pm 150(\mathrm{SPb}-1453) ; 6874 \pm 150(\mathrm{SPb}-$ 1450); $6920 \pm 150(\mathrm{SPb}-1451) ; 7065 \pm 150(\mathrm{SPb}-1448)$; $7088 \pm 150(\mathrm{SPb}-1449) ; 7037 \pm 27$ (KIA-39309); $7018 \pm 45$ (KIA-39308); $6860 \pm 31 \quad$ (KIA-39301); 6847 \pm 31 (KIA39300); $7356 \pm 30$ (KIA-39310); $7072 \pm 36$ (KIA-39311); $6395 \pm 28($ KIA-39312); $6371 \pm 30($ KIA-39313); $6740 \pm 90$ (Ki-14556); $6690 \pm 90$ (Ki-14554); $6410 \pm 90$ (Ki-14557); $6290 \pm 90 \quad$ (ГИН-12985); $6960 \pm 40 \quad$ (ГИН-12986); $7220 \pm 70$ (ГИН-12984), Становое 4/II (7030 \pm 100 (ГИН-8378) (рис. 1). 


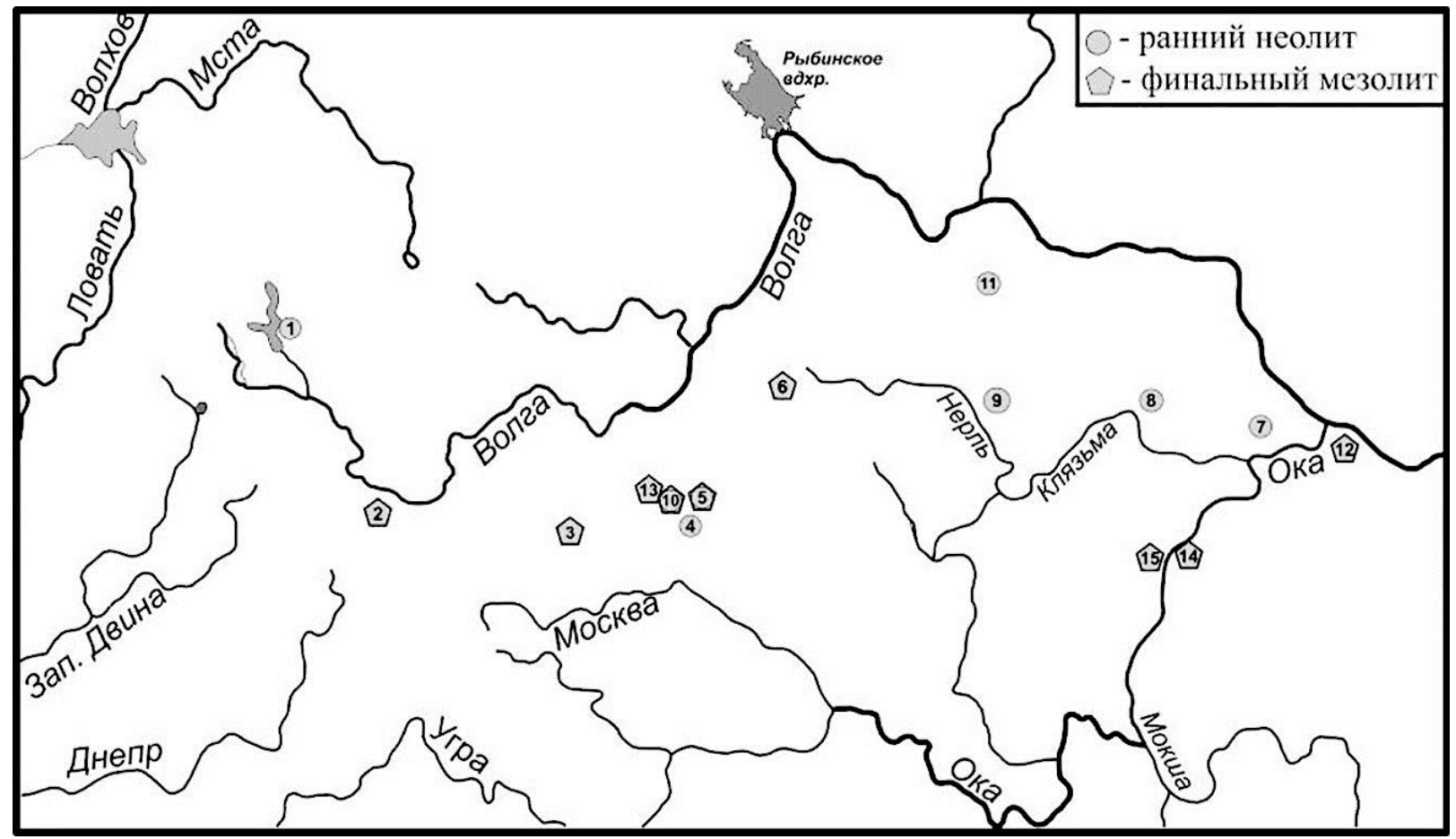

Рисунок 1 - Карта-схема расположения памятников финального мезолита - раннего неолита Верхневолжского региона, материалы которых использованы в статье. 1 - Котчище I, Нилова Пустынь; 2- Озерки 5/IV; 3- Берендеево III;

4- Давыдковская; 5- Замостье 2/верх. мез. сл., Замостье 2/4а; 6 - Ивановское VII/IIa; 7- Шадрино IV; 8- Алексеевское I; 9 - Сахтыш IIа/IIг; 10 - Окаёмово 4/III, 5, 18a, 18/III; 11 - Становое 4/II; 12 - Безводное 10; 13- Нушполы 11; 14- Новошино; 15- Елин Бор

Среди исследователей распространено мнение о наличии в культурных слоях таких стоянок финально-мезолитической примеси [например, 1, с. 213]. Как доказательство приводятся примеры налегания материалов раннего неолита на мезолитические находки на торфяниковых памятниках. Доказать/опровергнуть это сложно, поскольку различия между каменными индустриями финального мезолита и раннего неолита малозаметны и надёжно устанавливаются только на основании сравнительной статистики коллекций. Маркером хронологической позиции памятника служат находки ранней керамики в культурном слое.

\section{Обзор материалов}

Начальный этап неолита Верхней Волги характеризуется использованием преимущественно кремня различного цвета и качества, происходящего из отложений каменноугольного возраста. Среди него легко отличим сиреневый старицкий кремень, выходы которого известны в Тверском Поволжье. Изделия из него встречены на стоянках Котчище I, Нилова Пустынь, Окаёмово 18/III, Шадрино IV. Минимальная доля изделий на стоянках изготовлена из приносного высококачественного мелового сырья. Например, на стоянке Давыдковская использовался полупрозрачный светло-серый и черный кремень с меловой коркой [12, с. 146-157]. Также встречаются орудия из кварцита, сланца, песчаника и др.

Каменная индустрия начального неолита региона характеризуется следующими чертами. Наибольшее количество нуклеусов на стоянках этого времени объемного расщепления - с широким фронтом расщепления и торцовые (рис. 2: 6, 7, 11, 12, 15, 17, 18, 20-22,
24, 26; табл. 2). Ядрища условно-смешанного типа (рис. 2: 23) и бессистемного скалывания единичны.

Нуклеусы, сочетающие широкий и узкий фронты (условно-смешанный тип), представлены единственным ядрищем для пластин в Шадрино IV (рис. 2: 23). Аморфные нуклеусы найдены в Окаёмово 18/III 2 экз., Давыдковской - 1 экз.

Способы получения сколов-заготовок различны: жесткий отбойник, мягкий отбойник, посредник, отжим. Площадки всех призматических нуклеусов имеют следы подправки. Некоторые нуклеусы имеют угол скалывания близкий к $90^{\circ}$, что указывает на высокую вероятность использования отжимной техники. Единственный достоверно отжимный (карандашевидный) нуклеус найден в Шадрино IV (рис. 2: 16). Значительная часть ядрищ сильно истощена.

Пластины/микропластины-потенциальные заготовки (с негативами предшествующих продольных пластинчатых снятий) в большинстве своем фрагментированы и имеют нерегулярную огранку дорсальной поверхности (табл. 3).

Доля орудий, изготовленных из пластин, изменяется в широких пределах, от 17,5\% до 50\% (Алексеевское I - 45\% среди всех изделий со вторичной обработкой, Давыдковская - 22, 6\%, Замостье $2 / 4 \mathrm{a}-17$, $5 \%$, Котчище I - 39\%, Нилова Пустынь - 25\%, Окаёмово $18 / \mathrm{III}$ - 50\%, Становое 4/II - 14\% и Шадрино IV - 36\%). Для сравнения, на стоянках финального мезолита региона значения того же показателя составляют от $35 \%$ до 54\% (Сахтыш Іб - 35\%, Окаёмово $18 \mathrm{a}-54 \%$, Замостье $2-21 \%$, Окаёмово $4-35 \%$, Окаёмово 5 - 53\%, Ивановское VII/IIа, Ивановское III $31 \%)$. 
Цветкова Н.А.

Переход от мезолита к неолиту на Верхней Волге по результатам изучения...

Исторические науки и археология

Таблица 1 - Распределение категорий каменного инвентаря начального неолита на стоянках бассейна Верхней Волги

\begin{tabular}{|c|c|c|c|c|c|c|c|c|c|c|}
\hline Категории инвентаря & $\begin{array}{c}\text { Алек- } \\
\text { сеев- } \\
\text { ское } 1 \\
\end{array}$ & $\begin{array}{l}\text { Давыд- } \\
\text { ковская }\end{array}$ & \begin{tabular}{|c|} 
Замо- \\
стье \\
$2 / 4 \mathrm{a}$ \\
\end{tabular} & $\begin{array}{c}\text { Кот- } \\
\text { чище } \\
\text { I } \\
\end{array}$ & $\begin{array}{c}\text { Нилова } \\
\text { Пу- } \\
\text { стынь }\end{array}$ & \begin{tabular}{|c|} 
Ока- \\
ёмово \\
$18 / \mathrm{III}$ \\
\end{tabular} & $\begin{array}{c}\text { Сах- } \\
\text { тыш } \\
\text { IIA/IIг }\end{array}$ & $\begin{array}{c}\text { Ста- } \\
\text { новое } \\
4 / \mathrm{II} \\
\end{array}$ & \begin{tabular}{|c|} 
Шад- \\
рино \\
IV \\
\end{tabular} & $\begin{array}{c}\text { Ито- } \\
\text { го }\end{array}$ \\
\hline Пренуклеусы & - & 3 & - & - & - & 1 & - & - & - & 4 \\
\hline Нуклеусы & 2 & 10 & 1 & 3 & - & 3 & - & 2 & 3 & 24 \\
\hline $\mathrm{HK}$ & 6 & 1 & 4 & 7 & 1 & - & 5 & - & 3 & 27 \\
\hline Отщепы и их фрагменты & 133 & 2267 & 1808 & 1510 & 114 & 62 & 12 & 15 & 113 & 6034 \\
\hline Пластины и их фрагменты & 23 & 554 & 165 & 128 & 3 & 19 & - & 1 & 80 & 973 \\
\hline Абразивы & - & - & - & - & - & 3 & 2 & 1 & - & 6 \\
\hline Грузила & - & - & - & - & - & - & 2 & - & - & 2 \\
\hline Отбойники & - & 2 & - & 1 & - & - & 4 & - & - & 7 \\
\hline Пилы & 1 & - & - & - & - & - & 1 & - & - & 2 \\
\hline Ретушеры & - & 2 & - & 1 & - & - & - & - & - & 3 \\
\hline Наконечники стрел и их фрагменты & 1 & 3 & 5 & 5 & 1 & 3 & - & - & 1 & 19 \\
\hline Наконечники копий/дротиков & - & - & 1 & 2 & - & - & - & - & - & 3 \\
\hline Проколки & 3 & 5 & 27 & 6 & - & 2 & - & - & - & 43 \\
\hline Деревообрабатывающие & 4 & 4 & 3 & 1 & & 1 & 3 & 2 & 1 & 19 \\
\hline Заготовки деревообрабатывающих & 1 & 1 & & 1 & - & - & 2 & 1 & - & 6 \\
\hline Резцы & 2 & 11 & 1 & 6 & - & 5 & - & - & 3 & 28 \\
\hline Скребки & 5 & 53 & 27 & 34 & 1 & 5 & 2 & 3 & 16 & 146 \\
\hline Вкладыши & 5 & 4 & 9 & - & - & 2 & & 1 & 6 & 27 \\
\hline Пластины с регулярной ретушью & 3 & 3 & 24 & 14 & - & 1 & - & - & 10 & 55 \\
\hline Отщепы с регулярной ретушью & 5 & 1 & 4 & - & 2 & 1 & - & - & 1 & 14 \\
\hline Комбинированные орудия & 1 & - & 2 & 1 & - & 4 & - & - & 1 & 9 \\
\hline Неопределимые орудия & 1 & - & - & - & - & - & - & - & - & 1 \\
\hline Фрагменты орудий & - & 2 & - & 1 & - & - & & - & 2 & 5 \\
\hline Пластины с нерегулярной ретушью & 5 & 1 & - & 1 & - & 1 & - & 1 & 14 & 23 \\
\hline Отщепы с нерегулярной ретушью & 1 & - & - & - & - & - & 4 & - & 31 & 36 \\
\hline Сырье & 1 & - & - & - & - & - & 3 & 1 & - & 5 \\
\hline Итого & 203 & 2927 & 2081 & 1722 & 122 & 113 & 40 & 28 & 285 & 7521 \\
\hline
\end{tabular}

Таблица 2 - Типы нуклеусов кругового скалывания со стоянок начального неолита Верхневолжского бассейна

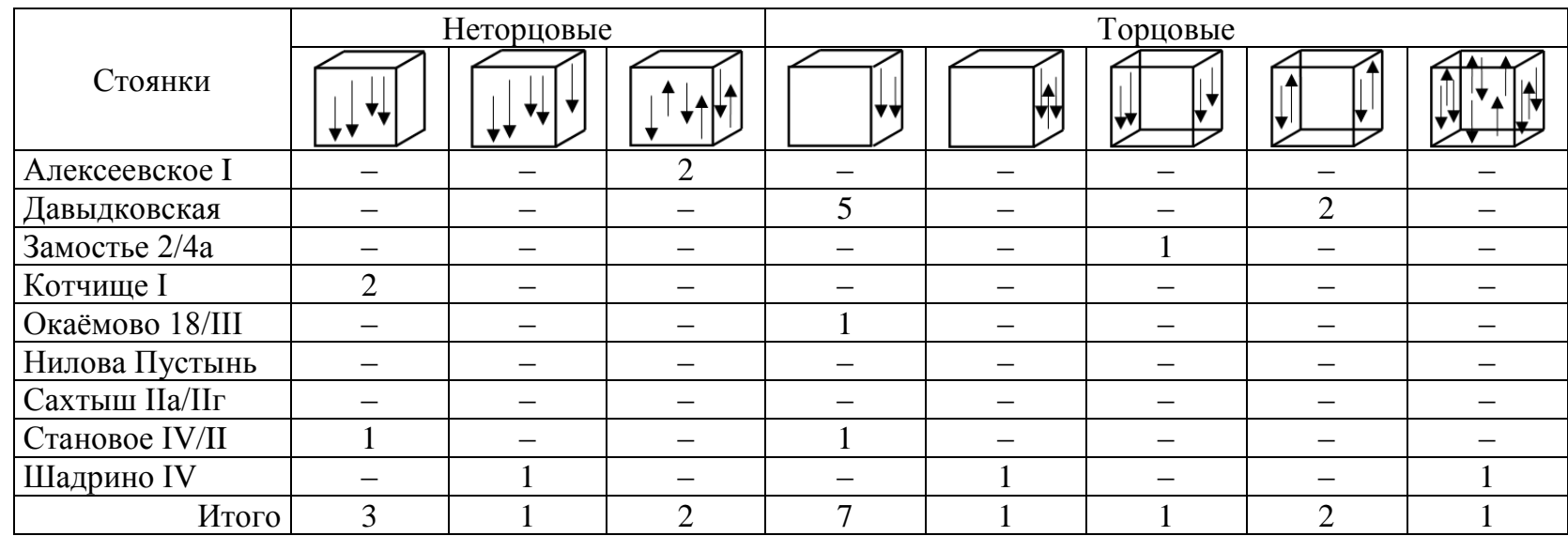

Таблица 3 - Технико-морфологические параметры пластин со стоянок начального неолита Верхней Волги

\begin{tabular}{|c|c|c|c|c|c|c|c|c|c|c|c|c|c|c|}
\hline Памятник & Д & $\mathrm{M}$ & $\Pi$ & $2 \Gamma$ & $3 \Gamma$ & $4 \Gamma$ & $5 \Gamma$ & $\mathrm{PO}$ & $\mathrm{HO}$ & Ц & ЖК & ШТП & КП & ККИ \\
\hline Алексеевское 1 & 2 & 18 & 3 & 6 & 13 & 4 & - & 8 & 15 & 4 & 6 & $7-15,30 / 2-4$ & 23 & 205 \\
\hline Давыдковская & + & + & + & + & + & $?$ & $?$ & + & + & $?$ & $?$ & $4-10 / ?$ & 554 & 3217 \\
\hline Замостье 2/4a & 14 & 21 & 16 & + & + & $?$ & $?$ & + & + & 10 & $?$ & $?$ & 165 & 311 \\
\hline Котчище I & + & + & + & 59 & 61 & 5 & 3 & 10 & 118 & 11 & 14 & $6-29 / 8-11$ & 128 & 1721 \\
\hline Нилова Пустынь & - & 2 & - & 3 & - & - & - & 1 & 2 & 1 & - & $12-15 / 2-5$ & 3 & 122 \\
\hline Окаёмово 18/III & 5 & 12 & 2 & 10 & 6 & 3 & - & 4 & 15 & 2 & - & $6-32 / 2-6$ & 19 & 113 \\
\hline Сахтыш ІІа/ІІг & - & - & - & - & - & - & - & - & - & - & - & - & - & - \\
\hline Становое 4/II & - & 1 & - & - & 1 & - & - & - & - & - & - & $12 / 2$ & 1 & 26 \\
\hline Шадрино IV & + & 29 & + & $?$ & $?$ & $?$ & $2+$ & $2+$ & + & 14 & & $6-9,16-17 / ?$ & 80 & 306 \\
\hline Итого & 21 & 83 & 21 & 78 & 81 & 12 & 5 & 25 & 150 & 41 & 20 & & 973 & 6021 \\
\hline
\end{tabular}

Примечание. Д - дистальные; $M$ - медиальные; $\Pi$ - проксимальные; $2 \Gamma$ - 2-гранные; $3 \Gamma$ - 3-гранные; $4 Г$ - 4-гранные; $5 \Gamma$ - 5-гранные; $P O$ - с рег. огранкой; $H O$ - с нерег. огранкой; $Ц$ - целые; ЖК - с желвачной коркой; ШТП - ширина/толщина пластин, мм; КП - кол-во пластин; ККИ - кол-во каменных изделий в коллекции. 

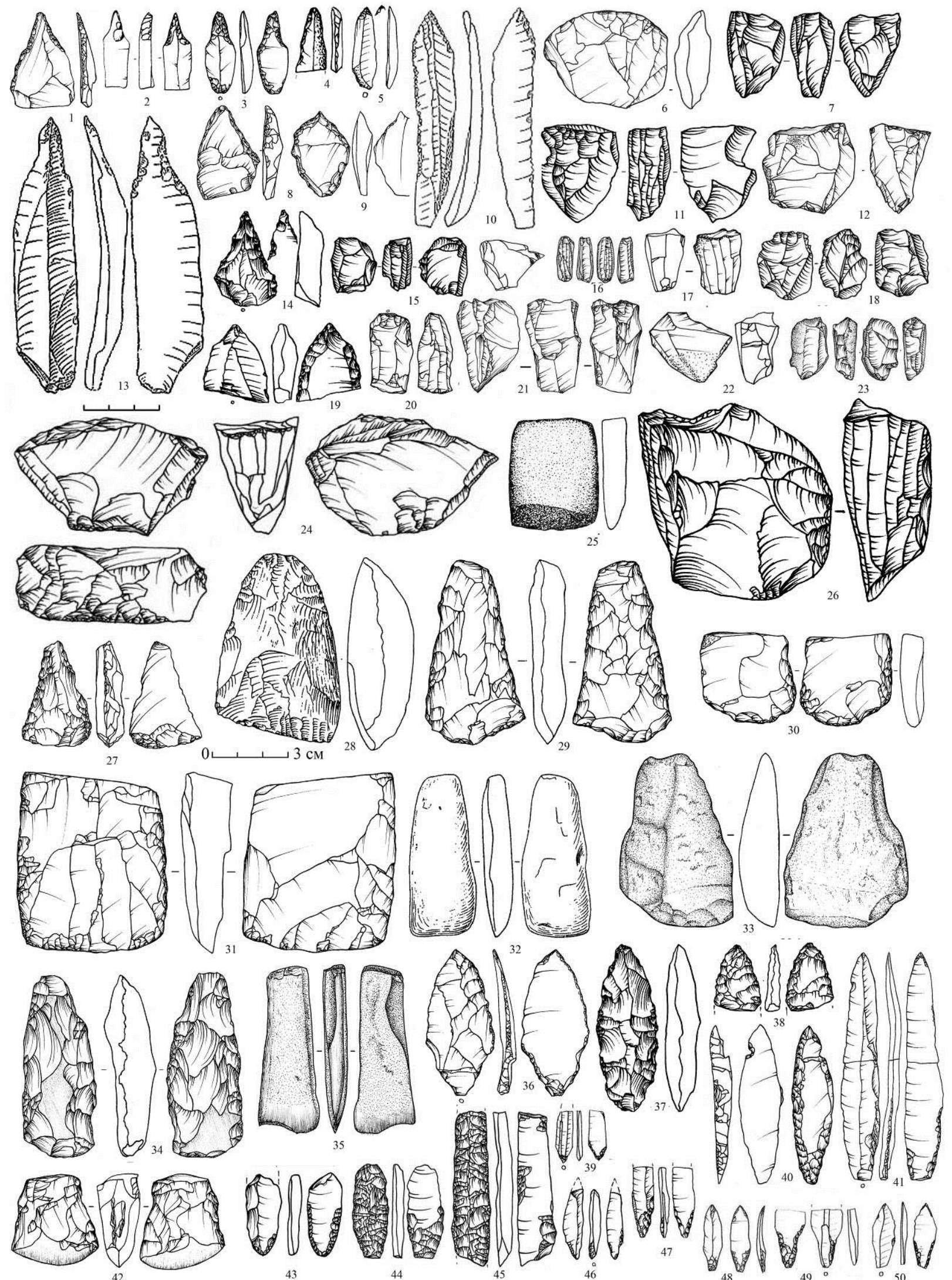

43
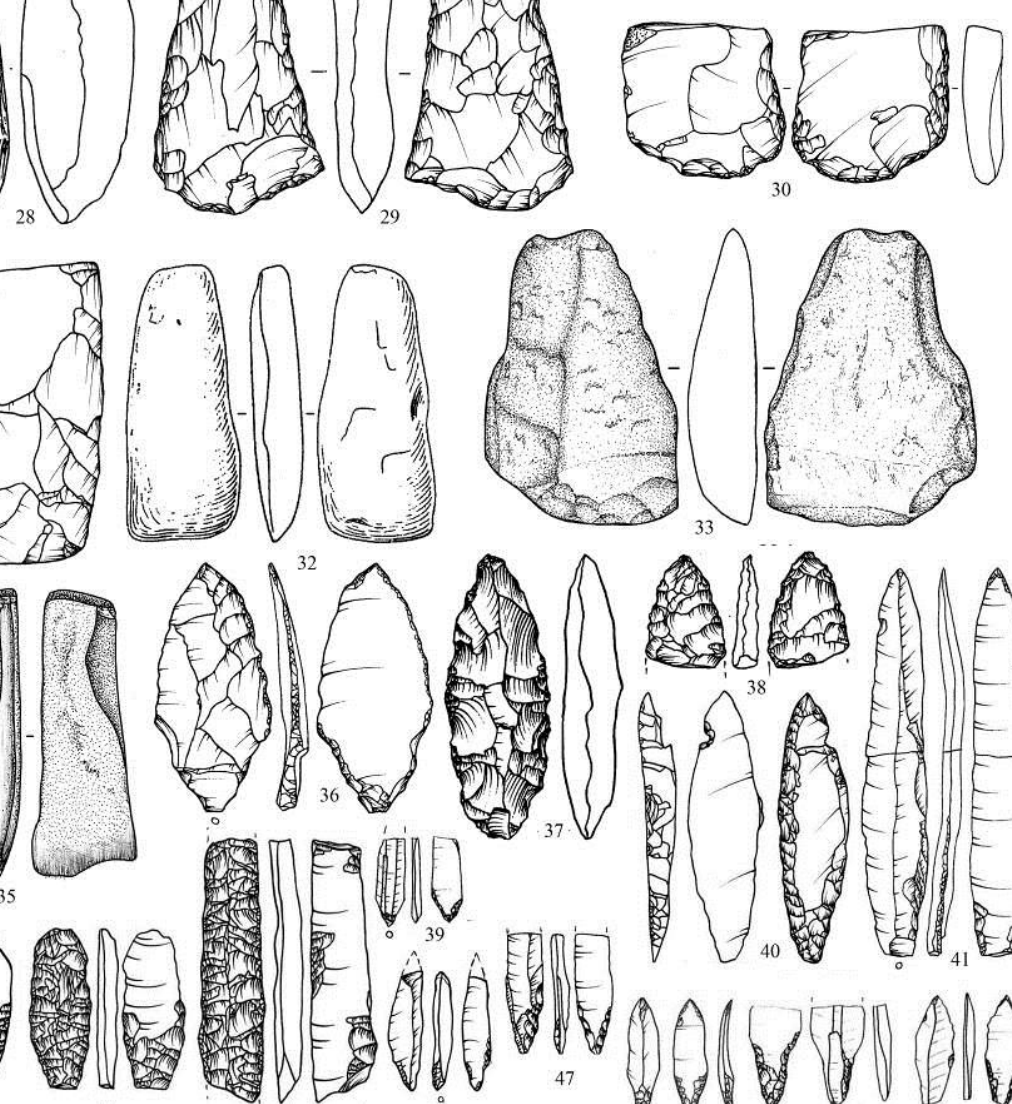

Рисунок 2 - Каменный инвентарь со стоянок начального неолита Верхней Волги. $1,3,6,8,9,21,24,27,31,36,40,44,45,48$ - Котчище I;

$2,4,12,20,29,30,42,47$ - Алексеевское I [13];

$5,39,49,50$ - Окаёмово 18/III [14]; 7, 10, 13, 15, 18, 26, 28, 32, 43, 46- Давыдковская [12]; $14,19,37$ - Замостье 2/4a [17]; 16, 23, 25, 38- Шадрино IV [15];

17, 22, 35 - Становое 4/II; 33, 34- Сахтыш ІІа/ІІг; 41 - Нилова Пустынь [15].

$1-4,6,8,9,12,16,17,20-24,27,29-31,33-36,38,40-42,44,45,47,48$ - рис. автора 
Цветкова Н.А.

Переход от мезолита к неолиту на Верхней Волге по результатам изучения.

Исторические науки и археология

Изделия-маркеры начального неолита, наконечники стрел с выделенным черешком (2 экз., рис. 2: $49)$ или листовидной формы (7 экз., рис. 2: 39, 41, 47, $48,50)$ изготовлены из пластин или микропластин с незначительной модификацией заготовки при помощи ретуши (подправка насада и острия). Пропорции наконечников очень удлиненные (3 экз.) либо средние (6 экз.). Единичны наконечники стрел, выполненные в той же технологической традиции, заготовкой для которых послужили отщеп (Котчище I (рис. 2: 40)) и пластинчатый отщеп (Давыдковская, (рис. 2: 43)). Наконечник из Котчища I - единственное орудие удлиненных пропорций с контурной ретушью, что объясняется спецификой заготовки (отщеп), потребовавшей большей модификации при изготовлении орудия, нежели только подработка пера и насада. Его стоит рассматривать как индивидуальную форму. К таковым могут быть также отнесены и наконечники-унифасы на пластинах, также найденные при раскопках стоянки Котчище I (рис. 2: 44, 45). Наконечники-унифасы известны как в финальном мезолите региона, так и в раннем неолите. Так, например, наконечники-унифасы происходят из ранненеолитического слоя Замостья 2, из той части поселения, где выделение слоя начального неолита из всего ранненеолитического горизонта невозможно. Фрагмент острия пера наконечника стрелы-бифаса со стоянки Шадрино IV представляет собой, при условии присутствия в коллекции единственного фрагмента ямочно-гребенчатого сосуда, примесь развитого неолита (рис. 2: 38) [13, с. 48]. Наконечник-бифас из Котчище I по характеру вторичной обработки бесспорно относится к развитому неолиту. Его присутствие объясняется соседним расположением со стоянкой Котчище I поздней стоянки.

Наконечники копий/дротиков редки для начального неолита. Два из них - это бифасы со стоянок Котчище I и Замостье 2/4a (рис. 2: 37). Третий предмет, с дорсальным сплошным ретушированием и вентральной полукрутой микроретушью, занимающей $3 / 4$ контура, найден в Котчище I (рис. 2: 36). Там же встречен фрагмент орудия, интерпретируемый как острие пера. По характеру вторичной обработки - это развито-неолитическая примесью, связанная с близким расположением позднего памятника (см. выше). Остальные два изделия-бифаса, с учетом контекста их обнаружения, относятся к раннему неолиту.

Характерными для каменной индустрии начального неолита Верхневолжского региона являются концевые скребки с дугообразным лезвием (тип 1). Количество таких изделий на отщепах в 2,5 раза превышает количество скребков на пластинах. Концевые скребки с прямым лезвием (тип 2), с «носиком» (тип 3) и стрельчатые (тип 4) формы единичны (табл. 4). Несмотря на то, что они не составляют значительных серий, они также в полной мере могут расцениваться как характерные для начального этапа неолита Верхневолжского региона [16] (рис. 3: 23-41).

Не имеет аналогов скребок с зубчатой ретушью со стоянки Котчище I (рис. 3: 36). Отдельно стоит охарактеризовать скребки из Замостье 2/4a. Концевые скребки представлены концевыми, боковыми формами; двойными скребками, скребками с обушком (всего 27 экз.). Также найдены 4 микроскребка на отщепах (с узким лезвием). Комбинированных скребков - 18 экз. [17, с. 76]. Более детальных сведений в публикации не представлено. Охарактеризовать согласно представленной классификации можно только опубликованные скребки (7 экз.).

Микроскребки представлены концевыми формами в коллекциях со стоянок Шадрино IV и Давыдковская (рис. 3: 16-17, 26, 29-32). Аморфные скребки - орудия без намеренно изготовленного скребкового лезвия, изготовленные на отщепах, в том числе фрагментированных, составляют $12,5 \%$ от общего количества скребков со стоянок начального неолита (табл. 4). Таким образом, утверждение о том, что к началу неолита количество аморфных скребков в инвентарях стоянок существенно возрастает [6, с. 64], неверно [16].

Для этого времени характерны угловые резцы с резцовыми кромками на сломе заготовки. Резцов на пластинах в два раза больше резцов на отщепах (табл. 5). Как правило, это орудия с одной кромкой. Двугранные и ретушные резцы единичны. В единственном экземпляре найден комбинированный резец (рис. 3: 20). Резец с рабочими кромками на боковых сторонах с одного конца заготовки, происходит со стоянки Давыдковская (рис. 3: 20). Резец из Котчища I имеет две рабочие кромки, расположенные сбоку на противоположных концах пластины [18].

Таблица 4 - Соотношение групп и типов скребков на стоянках начального неолита Верхневолжского региона

\begin{tabular}{|c|c|c|c|c|c|c|c|c|c|c|c|c|c|c|c|c|c|c|}
\hline \multirow{3}{*}{\begin{tabular}{|r|} 
Памятники \\
Группы \\
Типы
\end{tabular}} & \multirow{2}{*}{\multicolumn{4}{|c|}{$\begin{array}{c}\text { Пластина/пластинчатый } \\
\text { отщеп } \\
\text { Концевые }\end{array}$}} & \multicolumn{12}{|c|}{ Отщеп } & \multirow{3}{*}{$\begin{array}{c}\text { Аморф- } \\
\text { ные }\end{array}$} & \multirow{3}{*}{$\begin{array}{c}\text { Ито- } \\
\text { го }\end{array}$} \\
\hline & & & & & \multicolumn{4}{|c|}{ Концевые } & \multicolumn{4}{|c|}{ Контурные } & \multicolumn{4}{|c|}{ Боковые } & & \\
\hline & 1 & 2 & 3 & 4 & 1 & 2 & 3 & 4 & 1 & 2 & 3 & 4 & 1 & 2 & 3 & 4 & & \\
\hline Алексеевское 1 & 1 & - & - & - & 1 & - & - & - & - & - & - & - & - & - & - & - & - & 2 \\
\hline Давыдковская & 11 & 1 & - & - & 32 & - & - & - & 7 & - & - & - & - & - & - & - & 2 & 53 \\
\hline Котчище I & 3 & 1 & - & 3 & 13 & 4 & - & - & - & - & - & - & 1 & - & - & - & 9 & 34 \\
\hline Нилова Пустынь & 1 & - & - & - & - & - & - & - & - & - & - & - & - & - & - & - & - & 1 \\
\hline Окаемово 18/III & - & - & - & - & 2 & - & - & 1 & 1 & - & - & - & - & - & - & - & 1 & 5 \\
\hline Сахтыш 2a/ІІг & - & - & - & - & - & - & 1 & - & - & 1 & - & - & - & - & - & - & - & 2 \\
\hline Становое 4/II & - & - & - & - & 1 & - & - & - & - & - & - & - & - & - & - & - & 2 & 3 \\
\hline Шадрино IV & 4 & 1 & 1 & - & 7 & - & - & - & 1 & - & - & - & 2 & - & - & - & - & 16 \\
\hline Итого & 20 & 3 & 1 & 3 & 56 & 4 & 1 & 1 & 9 & 1 & - & - & 3 & - & - & - & 14 & 116 \\
\hline
\end{tabular}


Вкладыши представлены микропластинками 6 разновидностей из возможных 13, выявленных для мезолита - раннего неолита Верхней Волги (рис. 3: 1-11; табл. 6), [19, с. 136]. Регресс микропластинчатой техники в начальном неолите, по сравнению с мезолитом, не наблюдается. В каменной индустрии раннего мезолита доля вкладышей составляет от $1,1 \%$ до $35 \%$ среди орудий со вторичной обработкой. В среднем мезолите этот показатель изменяется от $1,1 \%$ до $20 \%$, а на памятниках финального мезолита не превышает $1,3 \%$. В раннем неолите микропластиноквкладышей - от $0,4 \%$ до $13 \%$. Такие показатели свидетельствуют об отсутствии четкой зависимости между возрастом памятника и количеством вкладышей $[19$, с. 148,149$]$. Следует также учитывать, что микропластинки без вторичной обработки - это потенциальные вкладыши.

Вкладышевое вооружение использовалось на Верхней Волге на протяжении всего мезолита и в раннем неолите. Некоторые типы орудий, например костяные плоские и игловидные наконечники с пазом, бытовали с начала мезолита. Другие, например наконечники с треугольным пером без шипов и с пазом на стержне, не составляют значительных серий и являются индивидуальными формами. Для начального неолита известны пять типов костяных орудий с пазами, три из которых (узкие уплощенные наконечники, однокрылые наконечники с шипом и прямые кинжалы) использовались, начиная с пребореала, а один (наконечники с биконической головкой), начиная с бореала [19, с. 146].

Проколки представлены изделиями с выделенным и с невыделенным жальцем. Зависимости от типа заготовки и формы проколок не прослеживается. Количество проколок на пластинах и отщепах рав- ное. Проколки с выделенным жальцем найдены на стоянках Алексеевское I (1 экз., рис. 2: 2), Давыдковская (1 экз., рис. 2: 13), Котчище I (3 экз., рис. 2: 3, 9). Орудия с невыделенным жальцем происходят из коллекций с памятников Алексеевское I (2 экз., рис. 2: 4), Давыдковская (4 экз., рис. 2: 10), Котчище I (3 экз., рис. 2: 1, 8), Окаёмово 18/III (2 экз., рис. 2: 5). На поселении Замостье 2/4а найдены 24 проколки и 3 сверла. Их детальное описание не представлено, в настоящей статье в статистику включены только проиллюстрированные 2 орудия [17, с. 80] (рис. 2: 14).

Топоры количественно превосходят тёсла в 5 раз. Наиболее распространенными среди обеих категорий являются трапециевидные орудия. Изделия треугольной и прямоугольной форм единичны. Технология изготовления деревообрабатывающих орудий раннего неолита предполагает использование двусторонней оббивки и абразивной обработки с применением разнообразных технических приемов. В их числе следует назвать прием «flake-axe», когда заготовкой для орудия выступает крупный отщеп, дистальный конец которого, требовавший минимальной обработки, предназначался для лезвия. У такой заготовки подтесывалась вентральная поверхность с боковых сторон, которые предварительно обрабатывались поперечными сколами [20, с. 125]. Встречено два изделия, изготовленных в такой технике (рис. 2: $27,31)$. Согласно способу обработки рубящих выделяются 4 типа: 1) орудия с двусторонней оббивкой; 2) с оббивкой дорсальной поверхности и вентральной подтеской пологой ретушью; 3) топоры и тёсла с оббивкой в сочетании с пришлифовкой; 4) шлифованные орудия (табл. 7). Вариантообразующим признаком являются пропорции орудий [подробнее см. 21, c. 205].

Таблица 5 - Соотношение групп и типов резцов на стоянках начального неолита на Верхней Волге

\begin{tabular}{|c|c|c|c|c|c|c|c|c|c|c|c|c|c|c|}
\hline \multirow{3}{*}{ Памятники } & \multicolumn{6}{|c|}{ На пластине/пластинчатом отщепе } & \multicolumn{6}{|c|}{ На отщепе } & \multirow{3}{*}{$\begin{array}{c}\text { Комби- } \\
\text { нир. }\end{array}$} & \multirow{3}{*}{$\begin{array}{c}\text { Bce- } \\
\text { го }\end{array}$} \\
\hline & \multicolumn{2}{|c|}{ Угловые } & \multirow{2}{*}{$\begin{array}{l}\text { Дву- } \\
\text { гран. }\end{array}$} & \multirow{2}{*}{\begin{tabular}{|c|} 
Ретуш- \\
ные
\end{tabular}} & \multicolumn{2}{|c|}{ Комбинир. } & \multicolumn{2}{|c|}{ Угловые } & \multicolumn{2}{|c|}{ Двугран. } & \multicolumn{2}{|c|}{ Ретушные } & & \\
\hline & $\begin{array}{c}1 \\
\text { кром- } \\
\text { ка }\end{array}$ & $\begin{array}{c}2 \\
\text { кром- } \\
\text { ки }\end{array}$ & & & $\begin{array}{c}1 \\
\text { кром- } \\
\text { ка }\end{array}$ & $\begin{array}{c}2 \\
\text { кром- } \\
\text { ки }\end{array}$ & $\begin{array}{c}1 \\
\text { кром- } \\
\text { ка } \\
\end{array}$ & $\begin{array}{c}2 \\
\text { кром- } \\
\text { ки }\end{array}$ & $\begin{array}{c}1 \\
\text { кром- } \\
\text { ка }\end{array}$ & $\begin{array}{c}2 \\
\text { кром- } \\
\text { ки } \\
\end{array}$ & $\begin{array}{c}1 \\
\text { кром- } \\
\text { ка }\end{array}$ & $\begin{array}{c}2 \\
\text { кром- } \\
\text { ки }\end{array}$ & & \\
\hline Алексеевское 1 & 1 & - & - & - & - & - & - & 1 & - & - & - & - & - & 2 \\
\hline Давыдковская & 3 & 1 & - & - & - & 1 & 3 & 1 & 2 & - & - & - & - & 11 \\
\hline Замостье 2/4a & - & - & - & - & - & - & 1 & - & - & - & - & & & 1 \\
\hline Кочище 1 & 4 & 1 & - & - & - & - & - & - & - & - & 1 & - & - & 6 \\
\hline Нилова Пустынь & - & - & - & - & - & - & - & - & - & & - & - & - & - \\
\hline Окаёмово 18/III & 4 & - & - & - & - & - & 1 & - & - & - & - & - & - & 5 \\
\hline Сахтыш ІІа/ІІг & - & - & - & - & - & - & - & - & - & - & - & - & - & - \\
\hline Становое 4/II & - & - & - & - & - & - & - & - & - & - & - & - & - & - \\
\hline Шадрино IV & 2 & - & - & - & - & - & & Ія 1 од & Ного $\mathrm{p}$ & езца ти & Іп неяс & $\mathrm{eH}$ & - & 3 \\
\hline Всего & 14 & 2 & - & - & - & 1 & 5 & 2 & 2 & - & 1 & - & - & 28 \\
\hline
\end{tabular}

Таблица 6 - Соотношение типов вкладышей на памятниках раннего неолита Верхней Волги

\begin{tabular}{|c|c|c|c|c|c|c|c|}
\hline \multirow[b]{2}{*}{ Стоянки } & \multicolumn{6}{|c|}{ Микропластинки } & \multirow[b]{2}{*}{$\begin{array}{c}\text { Ито- } \\
\text { го }\end{array}$} \\
\hline & $\begin{array}{c}\text { без ретуши/ } \\
\text { со следами } \\
\text { утилизации }\end{array}$ & $\begin{array}{c}\text { с мельчайшей } \\
\text { выравниваю- } \\
\text { щей край } \\
\text { ретушью }\end{array}$ & $\begin{array}{c}\text { с приостря- } \\
\text { ющей } \\
\text { ретушью } \\
\text { края/краев }\end{array}$ & $\begin{array}{c}\text { с притупли- } \\
\text { вающей } \\
\text { ретушью }\end{array}$ & $\begin{array}{c}\text { с поперечно } \\
\text { срезанными } \\
\text { ретушью } \\
\text { концом } \\
\end{array}$ & $\begin{array}{c}\text { со скошен- } \\
\text { ным рету- } \\
\text { шью концом }\end{array}$ & \\
\hline Алексеевское I & 4 & - & - & - & - & 1 & 5 \\
\hline Давыдковская & 2 & - & 2 & - & - & - & 4 \\
\hline Окаёмово 18/III & & & 1 & & 1 & & 2 \\
\hline Становое 4/II & 1 & - & - & - & - & - & 1 \\
\hline Шадрино IV & 2 & 1 & 1 & 2 & & - & 6 \\
\hline Итого & 9 & 1 & 4 & 2 & 1 & 1 & 18 \\
\hline
\end{tabular}


Цветкова Н.А.

Переход от мезолита к неолиту на Верхней Волге по результатам изучения..

Исторические науки и археология

Таблица 7 - Деревообрабатывающие орудия со стоянок начального неолита со стоянок начального неолита Верхней Волги [21]

\begin{tabular}{|c|c|c|c|c|c|c|c|c|c|c|c|c|}
\hline & Группа & Тип & $\begin{array}{l}\text { Алексе- } \\
\text { евское I }\end{array}$ & $\begin{array}{l}\text { Давыд- } \\
\text { ковская }\end{array}$ & $\begin{array}{c}\text { Замо- } \\
\text { стье } \\
2 / 4 a \\
\end{array}$ & $\begin{array}{c}\text { Котчи- } \\
\text { ще I }\end{array}$ & $\begin{array}{c}\text { Нилова } \\
\text { Пу- } \\
\text { стынь } \\
\end{array}$ & $\begin{array}{l}\text { Окае- } \\
\text { мово } \\
\text { 18/III } \\
\end{array}$ & $\begin{array}{c}\text { Сахтыш } \\
\text { ІІа/ІІг }\end{array}$ & $\begin{array}{l}\text { Стано- } \\
\text { вое 4/II }\end{array}$ & $\begin{array}{c}\text { Шад- } \\
\text { рино } 4\end{array}$ & $\begin{array}{c}\text { Ито- } \\
\text { го }\end{array}$ \\
\hline \multirow{12}{*}{ 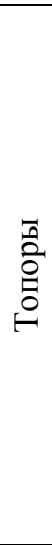 } & & Тип 1 & 1 & 2 & - & - & - & 1 & - & 1 & - & 5 \\
\hline & & Тип 2 & - & - & 1 & - & - & - & - & - & - & 1 \\
\hline & & Тип 3 & 2 & - & 1 & - & - & - & 2 & 1 & - & 6 \\
\hline & & Тип 4 & - & - & - & - & - & - & - & 1 & - & 1 \\
\hline & & Тип 1 & - & - & - & - & - & - & - & - & - & - \\
\hline & & Тип 2 & - & - & - & - & - & - & - & - & - & - \\
\hline & & Тип 3 & - & 1 & - & - & - & - & - & - & - & 1 \\
\hline & & Тип 4 & - & - & - & - & - & - & - & - & - & - \\
\hline & & Тип 1 & - & - & - & - & - & - & - & - & - & - \\
\hline & & Тип 2 & - & - & - & 1 & - & - & - & - & - & 1 \\
\hline & & Тип 3 & - & - & - & - & - & - & - & - & - & - \\
\hline & & Тип 4 & - & - & - & - & - & - & - & - & - & - \\
\hline \multirow{13}{*}{ 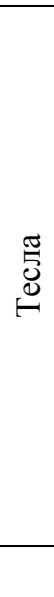 } & & Тип 1 & - & - & - & - & - & - & - & - & - & - \\
\hline & & Тип 2 & - & - & - & - & - & - & - & - & - & - \\
\hline & & Тип 3 & - & - & - & - & - & - & 1 & - & - & 1 \\
\hline & & Тип 4 & - & 1 & - & - & - & - & - & - & - & 1 \\
\hline & & Тип 1 & - & - & - & - & - & - & - & - & - & - \\
\hline & & Тип 2 & - & - & - & - & - & - & - & - & - & - \\
\hline & & Тип 3 & - & - & - & - & - & - & - & - & - & - \\
\hline & & Тип 4 & - & - & - & - & - & - & - & - & 1 & 1 \\
\hline & & Тип 1 & - & - & - & - & - & - & - & - & - & - \\
\hline & & Тип 2 & - & - & - & - & - & - & - & - & - & - \\
\hline & & Тип 3 & - & - & - & - & - & - & - & - & - & - \\
\hline & & Тип 4 & - & - & - & - & - & - & - & - & - & - \\
\hline & \multicolumn{2}{|c|}{ Итого } & 3 & 4 & 2 & 1 & - & 1 & 3 & 3 & 1 & 18 \\
\hline
\end{tabular}

К долотовидным изделиям относится единственное орудие со стоянки Алексеевское 1 (рис. 2: 30) крупный отщеп с двухсторонней крупнофасеточной полукрутой ретушью, образующей рабочее лезвие. Известны заготовки рубящих на разных стадиях изготовления (рис. 2: 31).

Сериями представлены пластины и отщепы с регулярной крутой/полукрутой и приостряющей ретушью в различных комбинациях: 1-сторонняя, 2-сторонняя, противолежащая. Случайные орудия - это пластины и отщепы с нерегулярной ретушью, аморфные скребки и микропластинки-вкладыши (табл. 1, 6).

Комбинированные орудия встречены в сочетаниях: «скребок + резец», «резец + нож», «резец + скобель», «резец + проколка». По мнению В.В. Сидорова, для раннего неолита региона характерны т.н. «нуклеусы-резцыл». В соответствии с технико-морфологическими характеристиками, данные изделия являются либо нуклевидными кусками, либо сильно истощенными нуклеусами [18, с. 264].

Известны также находки орудий для производства орудий: абразивов (Окаёмово 18/III, Сахтыш ІІа/ІІг, Становое 4/II), отбойников (Котчище I, Caxтыш ІІа/ІІг), сланцевых пил (Алексеевское I, Замостье 2, Сахтыш IІа/ІІг) и ретушеров (Давыдковская, Котчище I) (табл. 1; подробно об этом см. [22].

\section{Дискуссия}

Таким образом, каменную индустрию начального неолита Верхневолжского региона следует характеризовать как пластинчато-отщеповую. Её оценка по материалам памятников только с неорнаментирован- ной/тычково-накольчатой керамикой существенно уточняет известные представления. В первую очередь это касается роли пластины. Уже говорилось, что отличительной чертой этого времени исследователи считают регресс технологии производства пластин и микропластин. Наблюдения автора показывают, что оценка процентного соотношения пластин, микропластин и изделий из них, по сравнению с отщепами и изделиями из них, в каменных индустриях мезолита и неолита Верхней Волги является в определенном смысле искусственной и связана с неполнотой и неравнозначностью источников [19]. Вопервых, памятники отличаются друг от друга функциональными особенностями (охотничьи лагеря, мастерские, поселения, места разделки добычи и т.д.). Во-вторых, между ними имеются различия в длительности и периодичности обитания и/или посещения. Кроме того, степень их археологической изученности неравноценна. С другой стороны, доля орудий на пластинах, наличие нуклеусов для пластин и микропластин, количество пластин - потенциальных заготовок и высокая доля орудий на пластинах в коллекциях памятников раннего мезолита и начального неолита убедительно свидетельствуют о том, что традиция изготовления орудий на стандартизированной заготовке-пластине просуществовала в регионе 3500 лет, начиная с пребореала. На её существование никак не повлияли различия в качестве используемого сырья в зависимости от расположения стоянок в разных зонах обеспеченности кремнем [23]. 


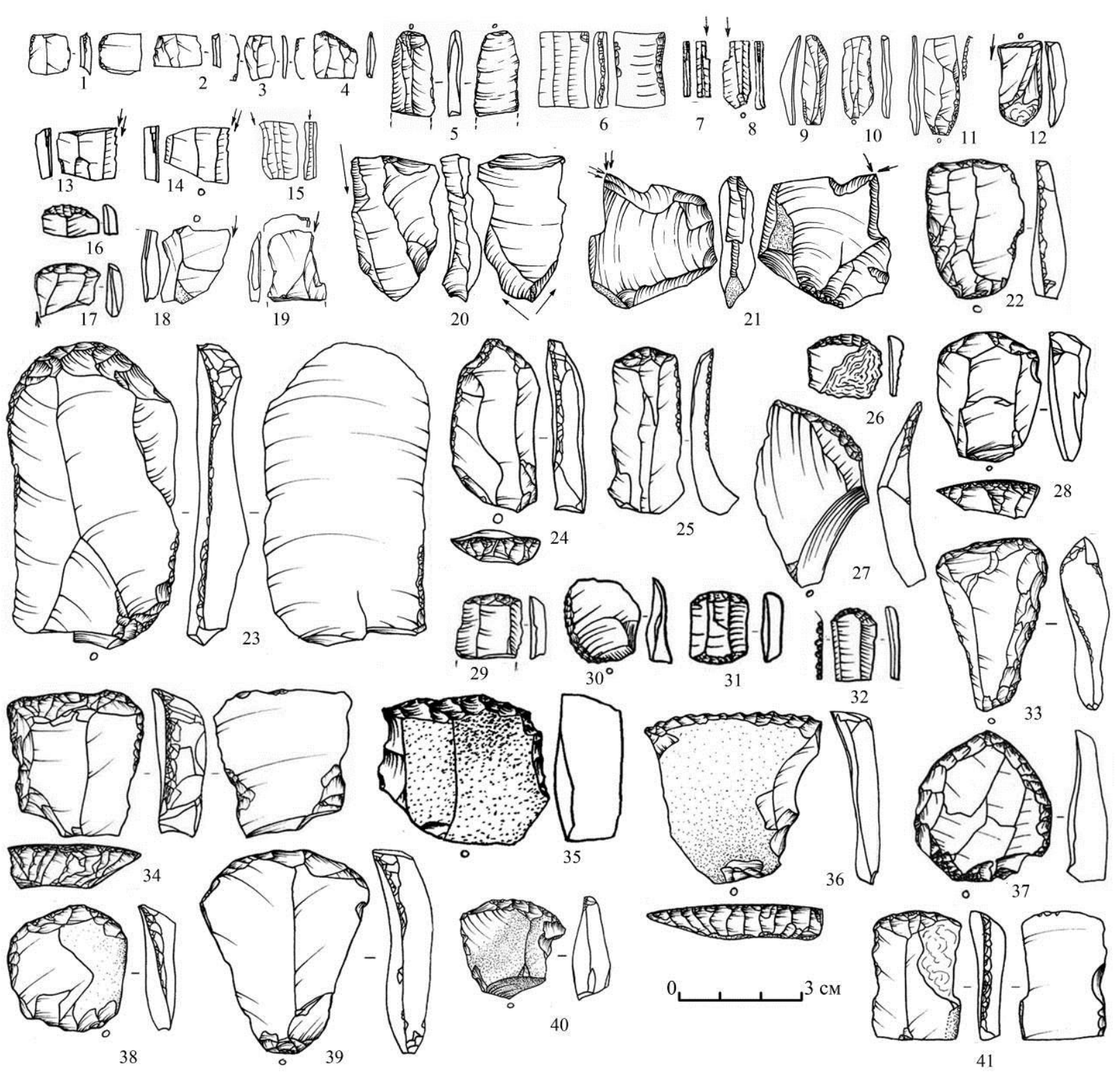

Рисунок 3 - Каменный инвентарь со стоянок начального неолита Верхней Волги.

1, 2, 4, 17- Алексеевское 1 [13]; 3- Становое 4/II; 5, 19, 12, 22, 24, 25, 27, 28, 33, 34, 36, 38-41 - Котчище I; $6,15,20,21,31$ - Давыдковская [12]; 13, 14, 18, 9, 11, 37- Окаёмово 18/III [14];

$7,8,10,16,26,29,30,32$ - Шадрино IV [13]; 23- Нилова Пустынь [15]; 35- Замостье 2/4а [17];

$1-5,10,12,17,19,22-25,27,28,29,33,34,36,38-41$ - рис. автора

Микропластинчатая техника на Верхней Волге вышла из употребления вместе с составным вооружением после 6500-6400 Uncal BP. Для этого же времени зафиксирована трансформация каменной индустрии из пластинчато-отщеповой в исключительно отщеповую и появление, помимо рубящих, других категорий орудий-бифасов, изготовленных в том числе с применением приёма утоньшения [4]. По результатам типологического анализа каменной индустрии ВВК можно говорить о последовательном существовании в раннем неолите региона двух различных, альтернативных друг другу технологических и культурных традиций изготовления орудий [11, с. 274-278]. Тогда же кардинально меняется и орнаментация керамических сосудов. На смену тычково-накольчатым элементам приходят прочерченные, ложношнуровые, зубчатые, гребенчатые. Сегодня доказано, что носители традиций археологиче- ских культур раннего неолита центральной части Европейской России, изготавливавшие посуду с тычково-накольчатыми и с «гребенчатыми» элементами, изначально неродственны друг другу [подробно об этом см. 24; 25; 26]. Таким образом, отказ населения Верхневолжского региона от микропластинчатой техники логичнее объяснять сменой населения, а не утратой навыка изготовления пластин.

Установленная высокая степень сходства между каменными индустриями начального неолита и финального мезолита [5; 6; 27] позволяет раскрыть детали перехода к неолиту на Верхней Волге. Феномен появления керамики в материальной культуре охотников-рыболовов-собирателей до сих пор до конца не ясен. На территории Европейской части России известны три наиболее ранних очага гончарства, откуда на Верхневолжский регион распространялись «культурные импульсы» [28, с. 45-48]. Появление 
первых глиняных сосудов на Верхней Волге связывается с продвижением в его пределы населения из южных/юго-восточных регионов [29; 30]. Эти выводы основаны на результатах изучения технологии изготовления и орнаментации керамики. Детальное сравнение каменных индустрий финального мезолита и раннего неолита по типам орудий для ВолгоОкского междуречья до сих пор не проводилось. Считается, что в условиях единых природноклиматических условий и схожих хозяйственных укладов возникает сложность с выявлением различий в каменном инвентаре этих эпох [29, с. 308]. Однако необходимость такого сравнения очевидна, поскольку разнородность или её отсутствие в типологическом составе орудийных наборов финального мезолита и раннего неолита может указывать на массовые подвижки населения (миграции) или же на разовые эпизоды (брачные связи, гостевые контакты).

Датированные стоянки с условно «чистыми» комплексами финального мезолита на Верхней Волге - это Безводное $10(6920 \pm 380$ (ГИН-5442)), Берендеево III (7770 \pm 100 (ЛЕ-1556)), Замостье 2/верх. мез. сл. (7450 \pm 100 (ГИН-6565), $7100 \pm 120$ (ГИН10066), $7460 \pm 20$ (ЛЕ-10094), $7450 \pm 70$ (ЛЕ-10091), $7440 \pm 60$ (ЛЕ-10092), $7400 \pm 75$ (ЛЕ-10260), $7350 \pm 45$ (ЛЕ-10090), $7270 \pm 120$ (ЛЕ-9524), $7050 \pm 60$ (ГИН10068), $7200 \pm 90$ (ГИН-7988)), Ивановское VII/IIa (7530 \pm 150 (ГИН-9361), $7520 \pm 60$ (ГИН-9361), $7490 \pm 120$ (ЛЕ-1260), $7375 \pm 170$ (ЛЕ-1261), $7320 \pm 190$ (ГИН9369)), Нушполы 11 (7310 40 (ГИН-6657)), Озерки 5/IV (7410 \pm 90 (ГИН-6659), $7310 \pm 120$ (ГИН-7218), $7190 \pm 180$ (ГИН-6660)), Окаёмово 4/III (7490 \pm 50 (ГИН-6204)), Окаёмово 5 (7910 \pm 80 (ГИН-6191), $7730 \pm 60$ (ГИН-6192)), Окаёмово $18 \mathrm{a} \quad(7420 \pm 50$ (ГИН-6656а)). К началу атлантикума на основании результатов палинологического анализа относят стоянки Новошино и Елин Бор/II [6, с. 72] (рис. 1). Сравнение типов орудий финального мезолита и раннего неолита региона представлено на рис. 4.

Как видно, сопоставление по типам орудий, так же как и в технике расщепления, подтвердило отсутствие различий между каменными индустриями финального мезолита и раннего неолита, что можно объяснить культурной преемственностью между населением этих эпох. Новые типы каменных орудий на стоянках с неорнаментированной/тычково-накольчатой керамикой не известны. В.М. Лозовский считал ранненеолитическим новшеством появление струйчатой ретуши [31, с. 85]. Однако она известна только для орудий из Замостье 2, найденных в слое, где в перемешанном виде залегает ранненеолитическая посуда всех типов. Столь редкое использование данного приема ретуширования говорит о том, что струйчатая ретушь как технический прием нехарактерна для раннего неолита бассейна Верхней Волги.

Начало неолита на Верхней Волге маркируется появлением глиняной посуды 7100/7000 Uncal BP без трансформации каменной индустрии. Ранняя керамика в совокупности с пластинчато-отщеповой индустрией встречается на стоянках возрастом до 6500-6400 Uncal BP. Очевидно, что каменный инвентарь и керамика этого хронологического отрезка отличаются от более поздних ранненеолитических комплексов Верхневолжского региона. Несмотря на то, что древности начального неолита были обособлены в отдельную историко-культурную единицу (волго-окская культура), ее скорее нужно рассматривать как поздне-мезолитическую, на финальном этапе развития которой появляется керамика. Нижняя хронологическая граница ВОК определяется появлением керамики с разреженной тычково-накольчатой орнаментацией, а верхняя - распространением отщеповой индустрии и посуды с ложношнуровой, прочерченной, «гребенчатой» орнаментацией вместе с исчезновением вкладышевого вооружения.

На сопредельных территориях исследователи отмечают появление отщеповых каменных индустрий и распространение орудий, изготовленных в бифасиальной технике также около 6500 Uncal BP, вместе с синхронным распространением традиций изготовления сложнорецептурной «гребенчатой» посуды [32, с. 368], за исключением карамышевской культуры [33, с. 133]. Обе категории источников обладают ярким типологическим сходством с древностями Верхней Волги.

Таким образом, мы сталкиваемся с ситуацией, когда на обширной территории фиксируются чрезвычайно схожие признаки в каменном инвентаре и в керамике. Их сходство, несмотря на принадлежность к разным культурам, настолько велико, что четко обозначить границы ареалов последних невозможно. В.В. Никитин характеризует взаимоотношения между носителями культур начального неолита лесной и лесостепной части Волжского бассейна как родственные и предлагает рассматривать археологические культуры начального неолита этой территории как части единой историко-культурной общности $[29$, с. 310$]$. Вопрос о территориальных границах общности ранней накольчатой керамики требует отдельного рассмотрения.

\section{Выводы}

Переход от мезолита к неолиту на Верхней Волге по данным изучения каменного инвентаря следует ассоциировать с разовыми контактами между автохтонным населением и носителями навыков изготовления глиняной посуды с разреженной тычковонакольчатой орнаментацией. Наиболее вероятно, что первая посуда попала в регион в готовом виде, доказательством чему являются: во-первых, малочисленность сосудов на стоянках; во-вторых, находки плоских донцев технологически совершенно вылепленной керамики, в целом не характерных для лесного неолита; в-третьих, примесь крупного шамота в ранней посуде, означающая наличие технологии изготовления керамики, основанной на традиции использования «старой» посуды. Поскольку наиболее ранняя посуда появляется практически одномоментно без сопровождения следов ее изготовления на месте, очевидно, что она являлась импортом.

Отсутствие различий между каменными индустриями финального мезолита и начального неолита указывает на отсутствие массового притока людей в регион. В противном случае в каменной индустрии начального неолита появились бы новые типы орудий, чего в реальности не зафиксировано. 
Цветкова Н.А.

\begin{tabular}{|c|c|c|c|c|c|}
\hline ТИПЫ ОРУДИЙ & $\mathrm{PH}$ & $\Phi \mathrm{M}$ & ТИПЫ ОРУдИй & PH & $\Phi \mathrm{M}$ \\
\hline $\begin{array}{l}\text { Наконечники стрел } \\
\text { с выделенным } \\
\text { черешком }\end{array}$ & $\begin{array}{l}\text { Давыдковская } \\
\text { Окаёмово 18/III }\end{array}$ & $\begin{array}{l}\text { Безводное 10; } \\
\text { Окаёмово 5; } \\
\text { Озерки 5/IV; } \\
\text { Ивановское 7/IIа } \\
\text { Елин Бор/II } \\
\end{array}$ & $\begin{array}{l}\text { Концевые } \\
\text { скребки с } \\
\text { дугообразным } \\
\text { лезвием }\end{array}$ & $\begin{array}{l}\text { Алексеевское I; } \\
\text { Давыдковская; } \\
\text { Котчище I; } \\
\text { Окаёмово 18/III } \\
\text { Становое IV/II; } \\
\end{array}$ & \multirow{3}{*}{$\begin{array}{l}\text { Ивановское VII/Ila; } \\
\text { Окаёмово 4/III; } 5 \text {; } \\
\text { Окаёмово18a; } \\
\text { Елин Бор/II, } \\
\text { Безводное 10; } \\
\text { Озерки 5/IV }\end{array}$} \\
\hline $\begin{array}{l}\text { Наконечники стрел } \\
\text { листовидные }\end{array}$ & $\begin{array}{l}\text { Нилова Пустынь } \\
\text { Котчище I } \\
\text { Окаёмово 18/III }\end{array}$ & $\begin{array}{l}\text { Окаёмово 4/III, 5; 18a; } \\
\text { Озерки 5/IV; } \\
\text { Ивановское 7/Ila } \\
\text { Елин Бор/II }\end{array}$ & $\begin{array}{l}\text { Концевые } \\
\text { скребки с } \\
\text { прямым } \\
\text { лезвием }\end{array}$ & $\begin{array}{l}\text { Шадрино IV } \\
\text { Котчише I }\end{array}$ & \\
\hline $\begin{array}{l}\text { Наконечники стрел } \\
\text { листовидные } \\
\text { унифасы }\end{array}$ & Котчище I & HET & $\begin{array}{l}\text { Концевые } \\
\text { скребки } \\
\text { с «носиком» }\end{array}$ & Сахтыш IIa/II & \\
\hline$\left\{\begin{array}{l}\text { Наконечники } \\
\text { копий/ } \\
\text { дротиков }\end{array}\right.$ & Котчище I & HET & товидные орудия & Алексеевское I & $\begin{array}{l}\text { Безводное 10; } \\
\text { Ивановское VII/IIa; } \\
\text { Озерки 5/IV }\end{array}$ \\
\hline $\begin{array}{l}\text { Наконечники } \\
\text { копий/дротиков }\end{array}$ & Замостье 2/4a & HET & 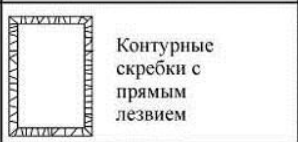 & Сахтыш ПІа/Іг & $\begin{array}{l}\text { Контурные } \\
\text { скреб̆ки с округлым } \\
\text { лезвием }\end{array}$ \\
\hline $\begin{array}{l}\text { Проколки с } \\
\text { выделенным } \\
\text { жальем }\end{array}$ & $\begin{array}{l}\text { Алексеевское I; } \\
\text { Давыдковская; } \\
\text { Замостье } 2 / 4 \text { a; } \\
\text { Котчище I }\end{array}$ & \multirow{2}{*}{$\begin{array}{l}\text { Безводное 10; } \\
\text { Елин Бор/II; } \\
\text { Ивановское VII/IIa; } \\
\text { Озерки 5/IV; } \\
\text { Океемово 5, 18a; } \\
\text { Нушполы 11/III }\end{array}$} & $\begin{array}{l}\text { Боковые } \\
\text { скребки }\end{array}$ & $\begin{array}{l}\text { Котчище I; } \\
\text { Шадрино IV }\end{array}$ & $\begin{array}{l}\text { Безводное } 10 ; \\
\text { Елин Бор/II; } \\
\text { Ивановское VII/IIa; } \\
\text { Озерки 5/IV }\end{array}$ \\
\hline $\begin{array}{l}\text { Проколки с } \\
\text { невыделенным } \\
\text { жальцем }\end{array}$ & $\begin{array}{l}\text { Давыдковская; } \\
\text { Замостье } 2 / 4 \text { a; } \\
\text { Котчище I }\end{array}$ & & $\begin{array}{l}\text { Аморфные } \\
\text { скребки }\end{array}$ & $\begin{array}{l}\text { Давыдковская; } \\
\text { Котчище I; } \\
\text { Окаёмово 18/III; } \\
\text { Становое 4/II } \\
\end{array}$ & \begin{tabular}{|l|} 
Безводное 10; \\
Елин Бор/II; \\
Ивановское VII/IIa \\
Озерки 5/IV \\
Окаёмово 5; 18a \\
\end{tabular} \\
\hline $\begin{array}{l}\text { Топоры } \\
\text { трапециевидные } \\
\text { с 2-сторонней } \\
\text { оббивкой }\end{array}$ & $\begin{array}{l}\text { Алексеевское I; } \\
\text { Давыдковская; } \\
\text { Окаёмово 18/III }\end{array}$ & $\begin{array}{l}\text { Елин Бор/II; } \\
\text { Озерки 5/IV } \\
\text { Окаёмово } 5 .\end{array}$ & $\begin{array}{l}\text { Вкладыши без } \\
\text { вторичной обработки/ } \\
\text { со следами } \\
\text { утилизации }\end{array}$ & $\begin{array}{l}\text { Алексеевское I, } \\
\text { Давыдковская, } \\
\text { Становое 4/II, } \\
\text { Шадрино IV }\end{array}$ & $\begin{array}{l}\text { Замостье 2/ } \\
\text { верх. мез. сл.; }\end{array}$ \\
\hline $\begin{array}{l}\text { रопоры с } \\
\text { 2-сторонней } \\
\text { вентральной подтеской }\end{array}$ & Замостье $2 / 4$ a & $\begin{array}{l}\text { Ивановское VII/IIa; } \\
\text { Окаёмово 18а }\end{array}$ & $\begin{array}{l}\text { Вкладыши с мельчайшей, } \\
\text { выравнивнивающей край } \\
\text { ретушью }\end{array}$ & Шадрино IV & Озерки 5/IV \\
\hline $\begin{array}{l}\text { Топоры и тесла с } \\
\text { оббивкой и } \\
\text { пришлифивкой }\end{array}$ & $\begin{array}{l}\text { Алексеевское I; } \\
\text { Замостье } 2 / 4 \mathrm{a} ; \\
\text { Сахтыш IIa/IIr; } \\
\text { Становое 4/II }\end{array}$ & $\begin{array}{l}\text { Безводное 10; } \\
\text { Елин Бор/II; } \\
\text { Ивановское VII/IIa } \\
\text { Озерки 5/IV. }\end{array}$ & $\begin{array}{l}\text { Вкладыши с } \\
\text { приостряющей } \\
\text { ретушью края/ } \\
\text { краев }\end{array}$ & $\begin{array}{l}\text { Давыдковская, } \\
\text { Окаёмово 18/III, } \\
\text { Шадрино IV }\end{array}$ & Озерки 5/IV \\
\hline $\begin{array}{l}\text { Топоры и тесла } \\
\text { полностью } \\
\text { шлифованные }\end{array}$ & $\begin{array}{l}\text { Становое 4/II } \\
\text { Давыдковская }\end{array}$ & HET & $\begin{array}{l}\text { Вкладыши с } \\
\text { притупливающей } \\
\text { ретушью края/ } \\
\text { краев }\end{array}$ & Шадрино IV & $\begin{array}{l}\text { Замостье } 2 / \\
\text { верх. мез. сл.; } \\
\text { Озерки 5/IV }\end{array}$ \\
\hline $\begin{array}{l}\text { Топоры с } \\
2 \text { 2-сторонней } \\
\text { оббовкой и } \\
\text { вентральной } \\
\text { подтеской }\end{array}$ & Давыдковская & Окаёмово $18 \mathrm{a}$ & $\begin{array}{l}\text { Вкладыши с } \\
\text { поперечно срезанным } \\
\text { ретушью концом }\end{array}$ & Окаёмово 18/III & $\begin{array}{l}\text { Безводное } 10 \text {; } \\
\text { Окаёмово } 5\end{array}$ \\
\hline 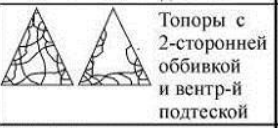 & Котчише I & Озерки 5/IV & $\begin{array}{l}\text { Вкладыши со } \\
\text { скошенным } \\
\text { ретушью концом }\end{array}$ & Алексеевское I & Ивановское VII/IIa \\
\hline $\begin{array}{l}\text { Тесла } \\
\text { шлифованные }\end{array}$ & Шадрино IV & $\begin{array}{l}\text { Озерки 5/IV; } \\
\text { Становое 4/III }\end{array}$ & $\begin{array}{l}\text { Пластины с крутой/ } \\
\text { полукрутой ретушью } \\
\text { (в разн. сочетаниях) } \\
\text { Замостье } 2 / 4 \mathrm{a}(?)\end{array}$ & \begin{tabular}{|l|} 
Алексеевское I, \\
Давыдковская, \\
Котчище I, \\
Окаёмово I8/III, \\
Шадрино IV, \\
\end{tabular} & \multirow{3}{*}{$\begin{array}{l}\text { Безводное 10; } \\
\text { Елин Бор/II; } \\
\text { Окаёмово 4/III; 5; } \\
\text { Окаёмово 18a; } \\
\text { Озерки 5/IV }\end{array}$} \\
\hline $\begin{array}{l}\text { Концевые скребки с } \\
\text { дугообразным лезвием }\end{array}$ & \begin{tabular}{|l|} 
Алексеевское I; \\
Давыдковская; \\
Котчище I; \\
Нилова Пустынь; \\
Шадрино IV \\
\end{tabular} & \multirow{3}{*}{$\begin{array}{l}\text { Ивановское VII/IIa; } \\
\text { Окаёмово 4/III; 5; 18a; } \\
\text { Елин Бор/II, } \\
\text { Безводное 10; } \\
\text { Озерки 5/IV }\end{array}$} & $\begin{array}{l}\text { Пластины с } \\
\text { приостряющей } \\
\text { ретушью } \\
\text { (в разн. соч-х) }\end{array}$ & $\begin{array}{l}\text { Давыдковская, } \\
\text { Котчище I, } \\
\text { Шадрино IV, } \\
\text { Замостье 2/4a (?) }\end{array}$ & \\
\hline $\begin{array}{l}\text { Концевые скребки с } \\
\text { прямым лезвием }\end{array}$ & $\begin{array}{l}\text { Давыдковская; } \\
\text { Котчище I; } \\
\text { Шадрино IV }\end{array}$ & & $\begin{array}{l}\text { Пластины с зубччатой } \\
\text { ретушью (пилки) }\end{array}$ & Замостье $2 / 4 a$ & \\
\hline $\begin{array}{l}\text { Концевые скребки } \\
\text { с «носиком» }\end{array}$ & Шадрино IV & & $\begin{array}{l}\text { Пластины с } \\
\text { выемками }\end{array}$ & $\begin{array}{l}\text { Котчище I, } \\
\text { Замостье } 2 / 4 \mathrm{a}\end{array}$ & HET \\
\hline $\begin{array}{l}\text { Стрельчатые } \\
\text { скребки }\end{array}$ & Котчище I & \multirow{2}{*}{$\begin{array}{l}\text { Безводное 10; } \\
\text { Елин Бор/II; } \\
\text { Озерки 5/IV }\end{array}$} & $\begin{array}{l}\text { Отщепы с } \\
\text { выемками } \\
\text { (скобели) }\end{array}$ & $\begin{array}{l}\text { Алексеевское I, } \\
\text { Шадрино IV }\end{array}$ & $\begin{array}{l}\text { Безводное 10; } \\
\text { Елин Бор/II; } \\
\text { Окаёмово 5; } \\
\text { Озерки 5/IV }\end{array}$ \\
\hline $\begin{array}{l}\text { Стрельчатые } \\
\text { скребки }\end{array}$ & Окаёмово 18/III & & $\begin{array}{l}\text { Отщепы с } \\
\text { пологой/полук-й } \\
\text { регулярной } \\
\text { ретушью }\end{array}$ & \begin{tabular}{|l|} 
Алексеевское I, \\
Давыдковская, \\
Замостье 2/4a \\
Окаёмово 18/III, \\
Нилова Пустынь \\
Шалрино IV \\
\end{tabular} & $\begin{array}{l}\text { Безводное 10; } \\
\text { Елин Бор/II; } \\
\text { Окаёмово 4/III; 5; } \\
\text { Окаёмово 18a; } \\
\text { Озерки 5/IV }\end{array}$ \\
\hline $\begin{array}{l}\text { Резщы угловые, } \\
1-2 \text { кромки }\end{array}$ & $\begin{array}{l}\text { Алексеевское I; } \\
\text { Давыдковская; } \\
\text { Котчище I; } \\
\text { Окаёмово 18; } \\
\text { Шадрино IV }\end{array}$ & $\begin{array}{l}\text { Безводное 10; } \\
\text { Елин Бор/II; } \\
\text { Ивановское VII/Ia; } \\
\text { Озерки 5/IV; } \\
\text { Окаёмово 5, 18a. }\end{array}$ & & Давыдковская & $\begin{array}{l}\text { Безводное 10; } \\
\text { Елин Бор/II } \\
\text { Озерки 5/IV }\end{array}$ \\
\hline $\begin{array}{l}\text { Резцы угловые, } \\
1-2 \text { кромки }\end{array}$ & $\begin{array}{l}\text { Алексеевское I; } \\
\text { Давыдковская; } \\
\text { Замостье } 2 / 4 \text { a } \\
\text { Окаёмово } 18 ;\end{array}$ & $\begin{array}{l}\text { Ивановское VII/Iа; } \\
\text { Окаёмово 4/III; } 18 \mathrm{a}\end{array}$ & Резцы ретушные & Котчище I & $\begin{array}{l}\text { Безводное } 10 \text {; } \\
\text { Елин Бор/II } \\
\text { Окаёмово } 5\end{array}$ \\
\hline
\end{tabular}

Рисунок 4 - Сравнительная характеристика типов орудий со стоянок финального мезолита и раннего неолита Верхней Волги 
Отсутствие культуроопределяющих орудий в древностях начального неолита Верхневолжского региона и сопредельных территорий, с одной стороны, и невозможность обозначить четкие границы ареалов археологических культур этого времени - с другой, позволяют говорить о единой культурной общности ранней керамики с разреженной тычковонакольчатой орнаментацией для центральной части Европейской России. Её характеризует пластинчатоотщеповый технокомплекс как «совокупность археологических памятников/групп памятников, выделяемых на одной ступени археологической периодизации в определенных пространственно-временных и природных границах» [34, с. 91]. Известные археологические культуры, в том числе и волго-окскую, следует воспринимать как условные географические подразделения культурного мира ранней накольчатой керамики, каждый из которых обладает индивидуальными чертами в рамках единых технологических каменной и керамической традиций.

Попав в мезолитическую среду, традиция изготовления ранней накольчатой посуды, не имела в ней длительного продолжения и была прервана притоком населения, обладавшего навыками изготовления посуды с «гребенчатой» орнаментацией из сложнорецептурного теста. Эпизоды, характеризующиеся появлением (7100/7000-6800 Uncal BP) и распространением (6800-6400 Uncal BP) керамики с разреженной тычково-накольчатой орнаментацией $[35$, c. 13] и не сопровождавшиеся существенными изменениями в облике каменного и костяного инвентаря, можно рассматривать как переходное время между мезолитом и неолитом, отображающее процесс неолитизации. Переход к неолиту, отмеченный изменением хозяйственного уклада, формированием местного очага производства керамики и распространением техники изготовления тонких бифасов, произошел позднее и был связан со сменой населения на Верхней Волге около 6500-6400 Uncal BP.

\section{Список литературы:}

1. Костылева Е.Л. Основные вопросы неолитизации центра Русской равнины (особенности неолитизации лесной зоны) // Неолит - энеолит юга и севера Восточной Европы (новые материалы, исследования, проблемы неолитизации регионов). СПб.: ИИМК PAH, 2003. C. 213-218.

2. Костылева Е.Л. Хронология, периодизация и локальные варианты верхневолжской ранненеолитической культуры: автореф. дис. ... канд. ист. наук. М., 1987.24 c.

3. Костылева Е.Л. Ранненеолитическая керамика Верхнего Поволжья // Тверской археологический сборник. Вып. 1. Тверь: ТГОМ, 1994. С. 53-57.

4. Энговатова А.В., Жилин М.Г., Спиридонова Е.А. Хронология верхневолжской ранненеолитической культуры (по материалам многослойных памятников Волго-Окского междуречья) // Российская археология. 1998. № 2. С. 11-21.

5. Жилин М.Г. Некоторые вопросы перехода от мезолита к неолиту на Верхней Волге // Проблемы изучения эпохи первобытности и раннего средневековья лесной зоны Восточной Европы. Вып. 1. Иваново: ГУ КПК Минтопэнерго, 1994. С. 19-31.
6. Кольцов Л.В., Жилин М.Г. Мезолит Волго-Окского междуречья. Памятники бутовской культуры. М.: Наука, 1999. 152 с.

7. Цетлин Ю.Б. Периодизация истории населения Верхнего Поволжья в эпоху раннего неолита (по данным изучения керамики) // Тверской археологический сборник. Вып. 2. Тверь: ТГОМ, 1996. С. 155-163.

8. Бобринский А.А. Гончарство Восточной Европы. М.: Наука, 1978. 272 с.

9. Цетлин Ю.Б. Неолит центра Русской равнины. Орнаментация керамики и методика периодизации культур. Тула: «Гриф и К», 2008. 352 с.

10. Костылева Е.Л., Уткин А.В., Энговатова А.В. Неолитические комплексы стоянки Ивановское VII // Мезолитические и неолитические культуры Верхнего Поволжья (по материалам стоянки Ивановское VII). М.: Наука, 2002. С. 40-63.

11. Цветкова Н.А. Ранний неолит бассейна Верхней Волги (по результатам изучения каменной индустрии) // Краткие сообщения Института археологии. 2012. Вып. 227. С. 271-280.

12. Сидоров В.В. Давыдковская стоянка на р. Яхроме // Советская археология. 1973. № 2. С. 146-157.

13. Жилин М.Г. Памятники мезолита и раннего неолита западной части Дубненского торфяника // Древности Залесского края: мат-лы к междунар. конф. «Каменный век Европейских равнин: объекты из органических материалов и структура поселений как отражение человеческой культуры». 1-5 июля 1997. Сергиев Посад: СПГИХМ, 1997. С. 164-196.

14. Цветкова Н.А. Ранненеолитическая стоянка Нилова Пустынь (по материалам работ В.И. Тимофеева в Тверской области) // Тверской археологический сборник. Вып. 11. Тверь: ТГОМ, 2018. С. 213-219.

15. Цветкова Н.А. Однослойные памятники раннего неолита Ивановской области // Материалы и исследования по археологии России и Белоруссии. Культурное взаимодействие древних сообществ кон. VII-II тыс. до н.э. верховьев Двины и Днепра (технологические и хозяйственные аспекты). СПб.: Инфинити, 2014. С. 42-60.

16. Цветкова Н.А. Скребки в раннем неолите Верхневолжского региона (сравнительная характеристика) // Тверской археологический сборник. Вып. 10 (1). Тверь: ТГОМ, 2015. С. 345-346.

17. Лозовская О.В., Лозовский В.М. О каменной индустрии раннего неолита на стоянке Замостье 2 // Методы изучения каменных артефактов: мат-лы междунар. конф. Санкт-Петербург, 16-18 ноября 2015 г. СПб.: ИИМК РАН, 2015. С. 72-81.

18. Цветкова Н.А. Резцы в раннем неолите Верхневолжского региона // Известия Самарского научного центра РАН. 2014. Т. 16, № 3. С. 260-265.

19. Цветкова Н.А. Вкладышевое вооружение мезолита - раннего неолита Верхневолжского региона // Stratum plus. 2017. № 1. C. 127-153.

20. Тарасов А.Ю. Адаптация к локальной сырьевой базе, технологическое развитие каменных индустрий и социальное развитие древних обществ: на примере культур Карелии периода неолита - раннего железного века // Адаптация культуры населения Карелии и особенности местной природной среды периодов мезолита - средневековья. Вып. 4. Петрозаводск: КНЦ РАН, 2009. С. 111-134. 
21. Цветкова Н.А. Ранненеолитические орудия для обработки дерева в Верхневолжском регионе // Тверской археологический сборник. Вып. 9. Тверь: ТГОМ, 2013. С. 202-217.

22. Цветкова Н.А. «Орудия для производства орудий» - изделия из некремневых пород камня (по материалам памятников раннего неолита Верхневолжского региона) // Проблемы изучения эпохи первобытности и раннего средневековья лесной зоны Восточной Европы: к 60-летию А.В. Уткина. Вып. IV. Иваново: Издатель Ольга Епишева, 2015. С. 161-164.

23. Жилин М.Г. Адаптация мезолитических культур Верхнего Поволжья к каменному сырью // Тверской археологический сборник. Вып. 3. Тверь: ТГОМ, 1998. С. 25-30.

24. Смирнов А.С. Памятники с накольчатой и гребенчатой орнаментацией в неолите Подесенья // Проблемы изучения раннего неолита лесной полосы Европейской части СССР. Ижевск: ИИЯЛ, 1988. С. 32-43.

25. Иванищева М.В. Хронология памятников раннего неолита Южного Прионежья // Проблемы хронологии и этнокультурных взаимодействий в неолите Евразии (хронология неолита, особенности культур и неолитизация регионов, взаимодействия неолитических культур в Восточной и Средней Европе). СПб.: ИИМК РАН, 2004. С. 60-69.

26. Цетлин Ю.Б. О происхождении верхневолжской культуры // Влияние природной среды на развитие древних сообществ (IV Халиковские чтения): мат-лы науч. конф., посв. 50-летию Марийской археологической экспедиции (Юрино, 5-10 августа 2006 г.). Йошкар-Ола: МНИИЯЛИ, 2007. С. 197-208.

27. Лозовский В.М. Переход от лесного мезолиту к лесному неолиту в Волго-Окском междуречье (по материалам стоянки Замостье 2) // Неолит - энеолит юга и севера Восточной Европы. Новые материалы, исследования, проблемы неолитизации регионов. СПб.: ИИМК РАН, 2003. С. 219-240.

28. Васильева И.Н., Выборнов А.А. «Очаги»/центры ранненеолитического гончарства в европейской части России // Традиции и инновации в изучении древнейшей керамики: мат-лы междунар. науч. конф. 24-27 мая 2016 года, Санкт-Петербург, Россия. СПб.: ИИМК РАН, 2016. С. 45-48.

29. Никитин В.В. Проблемные вопросы неолитизации Волжского бассейна // Человек, адаптация, культура. Тула: Изд-во «ЗАО Гриф и К», 2008. С. 307-313.

30. Вискалин А.В. Культурные процессы на Средней Волге в ранненеолитическую эпоху // Неолитические культуры Восточной Европы: хронология, палеоэкология, традиция: мат-лы междунар. науч. конф., посв. 75-летию Виктора Петровича Третьякова. Санкт-Петербург, 12-16 мая 2015. СПб.: ИИМК PAH, 2015. С. 26-28.

31. Лозовский В.М., Мазуркевич А.Н. Начальный этап раннего неолита Европейской части России // Российский археологический ежегодник. 2014. № 4. С. $73-88$.

32. Цветкова Н.А. Культурная история Верхневолжского региона в контексте раннего неолита центральной части Европейской России // Труды IV (XX) всерос. археологического съезда в Казани. Т. 1. Казань: Отечество, 2014. С. 367-370.

33. Цветкова Н.А. К проблеме определения археологических культур раннего неолита Русской равнины // Археологические источники и культурогенез. Таксоны высокого порядка в системе понятий археологии каменного века: тез. докл. конф., посв. 75-летию кафедры археологии СПбГУ, 5-6 декабря 2011 г. СПб.: СПбГУ, 2011. С. 131-134.

34. Лисицын С.Н. Технокомплексы рубежа плейстоцена-голоцена в лесной зоне Восточной Европы // Каменный век от Атлантики до Пацифики. Замятнинский сборник. Вып. 3. СПб.: МАЭ РАН, 2014. С. 85-109.

35. Зарецкая Н.Е., Костылева Е.Л. Радиоуглеродная хронология начального этапа верхневолжской ранненеолитической культуры // Российская археология. 2008. № 1. С. 5-14.

\title{
THE MESOLITHIC - NEOLITHIC TRANSITION IN THE UPPER VOLGA REGION RESULTED FROM THE STONE INDUSTRY ANALYSES
}

(C) 2019

\author{
Tsvetkova Nataliya Aleksandrovna, specialist of Scientific Documentation Department
} The Russian Museum of Ethnography (Saint Petersburg, Russian Federation)

Abstract. The paper deals with a phenomenon of neolithisation in the Upper Volga basin. The author studies the results of culture processes in the region based on: 1) the investigation of the stone assemblages from reference sites with non-ornamented ceramics or pottery with simple puncture impressions; 2) the tools types comparison over the final Mesolithic and initial Neolithic; 3) mapping of the non-ornamented/notch-ware pottery in European Russia. The transition to the Neolithic is associated with infiltrations of some puncture-ware pottery makers into the indigenous Mesolithic populations. It is most likely that the first vessels were imported into the region by migrants. The untraceable differences between the Final Mesolithic and the Early Neolithic stone industries may indicate a scarcely noticeable infiltration of newcomers from neighboring territories to the Upper Volga region. The manufacture tradition of the ceramics either non-ornamented or decorated by simple puncture impressions was formed in the regional culture environment. This event should be regarded as a particular transition time from the Mesolithic to the Neolithic. The later rise of the Neolithic was marked by shifts in the economy and by the local ceramic manufacture development accompanied by thin biface technique appearance in the stone assemblages. These changes give evidence of a transition to the Neolithic in the Upper Volga signalized by the progressive replacement of populations.

Keywords: Upper Volga region; Final Mesolithic; Initial Neolithic; neolithisation; cultural genesis; Volga-Oka culture; Upper-Volga culture; simple-puncture-ware ceramics; comb-ware ceramics; stone inventory; stone industry; techno-complex; archaeological culture; cultural community. 